\title{
ANALISIS TINGKAT KEPUASAN KONSUMEN DI RESTORAN LUMBUNG KAWANUA MANADO
}

\section{ANALYSIS OF CONSUMER SATISFACATION LEVEL AT LUMBUNG KAWANUA RESTAURANT MANADO}

\author{
$\underline{\text { Agus Saputra Sitepu }}^{(1)}$, Joachim Noch Karel Dumais ${ }^{(2)}$, Noortje Marsellanie Benu ${ }^{(2)}$ \\ 1) Mahasiswa Program Studi Agribisnis, Fakultas Pertanian, Universitas Sam Ratulangi, Manado \\ 2) Dosen Program Studi Agribisnis, Fakultas Pertanian, Universitas Sam Ratulangi, Manado \\ *Penulis untuk korespondensi: agussitepu034@student.unsrat.ac.id
}

Naskah diterima melalui Website Jurnal Ilmiah agrisosioekonomi@unsrat.ac.id

Selasa, 13 April 2021

Disetujui diterbitkan

Jumat, 28 Mei 2021

\begin{abstract}
The objective of this research is to measure the level of customer satisfaction at Lumbung Kawanua restaurant in terms of product, price, place, promotion and service aspects. This research was conducted from September to October 2020, using primary and secondary data with accidental sampling method technique and 40 respondents. The analytical method used is descriptive data analysis which describes the level of customer satisfaction of Lumbung Kawanua Restaurant Manado, to measure the level of customer satisfaction at the Lumbung Kawanua restaurant in Manado, a Likert scale is used. The research results showed that the index score of customer satisfaction perceptions of the Level of Customer Satisfaction at Lumbung Kawanua Restaurant in Manado was $86.5 \%$ and was classified as very satisfied.
\end{abstract}

Keywords: satisfacation level; consumer; restaurant

ABSTRAK

Penelitian ini bertujuan untuk untuk mengukur tingkat kepuasan konsumen restoran Lumbung Kawanua dilihat dari aspek product, price, place, promotion dan service. Penelitian ini dilaksanakan pada bulan September sampai Oktober 2020, menggunakan data primer dan sekunder dengan teknik pengambilan sampel metode accidental sampling dan responden sebanyak 40 orang. Metode analisis yang digunakan adalah analisis data deskriptif yang menggambarkan Tingkat Kepuasan Konsumen Restoran Lumbung Kawanua Manado. Untuk mengukur Tingkat Kepuasan Konsumen Restoran Lumbung Kawanua Manado, di gunakan Skala Likert. Hasil penelitian menunjukkan bahwa angka indeks persepsi kepuasan konsumen terhadap Tingkat Kepuasan Konsumen Restoran Lumbung Kawanua Manado adalah sebesar 86.5\% yang tergolong sangat puas (SP).

Kata kunci: tingkat kepuasan; konsumen; restoran 


\section{PENDAHULUAN}

\section{Latar Belakang}

Restoran merupakan bidang usaha yang menuntut penekanan pada kualitas pelayanan tinggi dan perbaikan kualitas secara berkesinambungan. Mengingat bahwa terjadi perubahan gaya hidup konsumen dan budaya makan diluar menjadi sangat umum dilakukan, maka konsumen menginginkan pengalaman rasa yang enak, suasana yang nyaman dan pengalaman yang menyenangkan selama dalam proses mengkonsumsi jasa kuliner. Sektor kuliner tidak hanya mengedepankan aspek makanan dan minuman yang disajikan, tetapi proses dan tahapan penyajian serta suasana pelayanan juga ikut memberikan kontribusi bagi terciptanya kepuasan konsumen (Novrianto, 2016).

Kepuasan konsumen merupakan indikator utama dari standart suatu fasilitas dan sebagai suatu ukuran mutu pelayanan yang diberikan. Kepuasaan konsumen dapat dicapai melalui hasil kinerja yang terbaik dalam memberikan pelayanan kepada pelanggan. Jika konsumen merasa puas terhadap semua indikator maka secara tidak langsung akan mempromosikan produk tersebut kepada orang-orang terdekat. Kualitas pelayanan merupakan salah satu faktor penting dalam meningkatkan daya saing. Harapan dari konsumen setiap saat selalu berubah sehingga kualitas pelayanan yang diberikan juga harus disesuaikan. Konsumen akan menilai pelayanan yang diberikan oleh suatu perusahaan dan membandingkannya dengan perusahaan lain yang sejenis, juga membandingkan pelayanan yang diterima dengan pelayanan yang diharapkan (Dianto, 2013). Konsumen saat ini sangat nyaman dalam menentukan kemana akan menjatuhkan pilihan tempat makan. Hampir di setiap jalan tersedia pilihan alternatif kuliner, mulai dari yang kelas kaki lima, warung-warung makan, restoran hingga tempat-tempat lain yang selain menjual cita rasa masakan, juga menawarkan kenyamanan lebih yang terkadang harus dibayar dengan lebih mahal oleh konsumen. Kombinasi antara kualitas menu dan suasana lokasi di tempat makan, merupakan perpaduan yang banyak dicari oleh konsumen saat ini. Hal ini dikarenakan budaya untuk makan diluar rumah, selain menjadi kebutuhan pangan yang pokok, namun momentum ini sering dijadikan pula sebagai sarana melepas keletihan dan untuk menyegarkan pikiran. Memandang lingkungan yang berbeda, sejuk, nyaman, dipercaya oleh konsumen dapat menambah kenikmatan dalam menyantap hidangan makanan. Tak heran saat ini banyak tempat kuliner juga melengkapi tempat usahanya dengan fasilitas-fasilitas yang dapat memberikan kenyamanan bagi pelanggannya, seperti meja kursi yang nyaman, toilet yang bersih dan wangi, hotspot gratis, layar TV proyektor sebagai hiburan sambil menunggu makanan dihidangkan, tempat parkir yang lapang dan aman, sarana bermain anak- anak, dan lain sebagainya.Yang penting juga adalah kualitas pelayanan personil restoran itu sendiri. Merekalah yang pertama kali berinteraksi dengan pelanggan, mulai dari penyambutan, mencatat pesanan, mengolah masakan, mengantarkan makanan, hingga kepada membersihkan meja yang dapat memuaskan konsumen.

Kota Manado merupakan salah satu kota yang banyak berdiri usaha dibidang kuliner seperti Restoran hal ini dikarenakan masyarakat Manado yang sangat terkenal dengan masyarakat yang hobi makan, hal inilah yang mengakibatkan bisnis kuliner tumbuh pesat di Kota Manado baik dari makanan pokok hingga makanan ringan. Sebagian masyarakat Kota Manado memilih makan di luar karena mereka mencari yang praktis, cepat, dan nyaman. Berkembangnya jumlah restoran di Kota Manado berdampak pada peningkatan persaingan bisnis yang ketat sesama restoran di Kota Manado. Hal ini mendorong pengusaha untuk membangun dan memperkuat usahanya agar tetap dipilih oleh konsumen. Setiap restoran berusaha memberikan menu-menu dan pelayanan terbaiknya agar mampu bersaing dengan restoran lain. Salah satu restoran yang berada pada persaingan tinggi antar bisnis restoran di Kota Manado adalah Restoran "Lumbung Kawanua" yang berlokasi di Jl.W.Z. Johanes, Bumi Nyiur Kec. Wanea, Kota Manado.

Restoranan Lumbung Kawanua ini menyajikan makanan yang berasal dari bahan utama yaitu ikan, ayam dan masakan khas Manado dengan menghasilkan produk makanan seperti ikan cakalang yang dibakar, ikan asin, ayam bakar rica, ayam kampung bakar, dan lainlain. Restoran Lumbung Kawanua juga menyediakan makan perpaket yang dilengkapi, 
sayur kangkung dan nasih putih dan disempurnakan dengan bumbu-bumbu yang diambil dari bahan- bahan pertanian. Dalam menghadapi persaingan, Restoran "Lumbung Kawanua" dituntut untuk dapat menerapkan strategi agar mampu memenuhi keinginan dan kebutuhan konsumen. Saat ini perhatian restoran terhadap kepuasan maupun ketidakpuasan konsummen telah semakin besar. Persaingan yang semakin ketat dimana semakin banyak restoran yang terlibat dalam pemenuhan kebutuhan dan keinginan konsumen akan produk atau jasa adalah tujuan utama restoran tersebut. Pemenuhan kepuasan konsumen sangatlah penting di karenakan konsumen merupakan salah satu factor keberhasilan suatu restoran. Jika restoran tidak jeli dalam mempelajari sikap konsumen maka produk dari suatu restoran tidak akan bertahan lama di hadapan konsumen dan akan tersaingi oleh restoran lain.

Untuk mempertahankan pelanggan, restoran Lumbung Kawanua harus terlibat langsung dalam pemenuhan kebutuhan dan kepuasan pelanggan. Hal ini harus mendapat perhatian dengan tidak melupakan upaya mendapatkan pelanggan yang baru. Dengan terciptanya kepuasan terhadap pelayanan, kenyamanan, fasilitas yang ada dalam restoran akan membawa beberapa manfaat diantaranya adalah terciptanya komunikasi mulut ke mulut yang positif terhadap restoran maupun terciptanya kesetiaan konsumen terhadap pembelian produk terhadap restoran tersebut (Hardyasar,2017).

\section{Rumusan Masalah}

Adapun rumusan masalah dari penelitian ini adalah Bagaimana Tingkat Kepuasan Konsumen Restoran Lumbung Kawanua dilihat dari aspek product, price, place, promotion dan service?

\section{Tujuan Penelitian}

Penelitian ini bertujuan untuk mengukur tingkat kepuasan konsumen di Restoran Lumbung Kawanua dilihat dari aspek product, price, place, promotion dan service.

\section{Manfaat Penelitian}

Adapun manfaat dari penelitian ini nantinya yaitu:

1. Bagi peneliti, sebagai sarana penambah wawasan serta pengetahuan tentang indeks kepuasan konsumen, mengenai faktor apa saja yang mempengaruhi kepuasan konsumen, sehingga suatu usaha dapat berjalan secara berkelanjutan.

2. Bagi peneliti lain, dapat dijadikan sebagai sarana referensi untuk melakukan penelitian lanjutan atau penelitian yang lebih mendalam pada bidang yang sama.

3. Bagi Restoran, dapat dijadikan sebagai informasi serta bahanpertimbangan untuk menentukan langkah-langkah yang akan digunakan dalam peningkatan kualitas demi mencapai dan meningkatkan kepuasan konsumen.

\section{METODE PENELITIAN}

\section{Waktu dan Tempat Penelitian}

Penelitian dilakukan di Restoran "Lumbung Kawanua" yang berlokasi di Jl.W.Z. Johanes, Bumi Nyiur Kec. Wanea, Kota Manado. Pemilihan lokasi penelitian dilakukan dengan metode purposive sampling, yaitu teknik pemilihan lokasi penelitian secara sengaja dengan mempertimbangkan aspek-aspek tertentu. Penelitian ini dilaksanakan pada bulan September 2020 sampai bulan Oktober 2020.

\section{Metode Pengumpulan Data}

Jenis dan sumber data yang digunakan dalam penelitian ini adalah data primer dan data sekunder. Data primer merupakan data dari hasil wawancara dengan karyawan dan hasil pengisian kuesioner oleh konsumen Restoran Lumbung Kawanua Manado. Data Sekunder diperoleh dari buku-buku, jurnal penelitian dan literatur- literatur yang berkaitan dengan pembahasan permasalahan yang memiliki hubungan dengan penelitian ini. 


\section{Metode Pengambilan Sampel}

Pengambilan sampel menggunakan metode Accidental sampling yaitu penentuan sampel secara kebetulan, yaitu siapa saja yang secara kebetulan bertemu dengan peneliti di Restoran Lumbung Kawanua Manado dapat digunakan sebagai sampel. Peneliti akan melakukan pengambilan sampel pada saat restoran buka hingga tutup dari pukul 08.00 21.00 dan memilih siapa saja yang ditemui dilokasi penelitian dan bersedia untuk dijadikan sebagai responden. Responden ini adalah konsumen yang bersedia untuk diwawancarai dengan kuesioner. Responden yang akan diambil sebanyak 40 responden karena konsumen yang mampir ke restoran Lumbung Kawanua kurang dari 20 orang per harinya. Responden yang dipilih adalah konsumen yang pada saat itu sedang berada di Restoran Lumbung Kawanua Manado.

Dalam menghitung jumlah sampel digunakan rumus Slovin, rumus slovin adalah sebuah rumus atau formula yang biasa digunakan dalam penelitian survey dimana biasanya jumlah sampel besar sehingga di perlukan sebuah formula untuk mendapatkan sampel yang sedikit tetapi dapat mewakili keseluruhan populasi.

Rumus Slovin adalah sebagai berikut:

$$
n=\frac{N}{1+N e^{2}}
$$

Berdasarkan rumus Slovin diatas, maka apabila Restoran Lumbung Kawanua Manado mempunyai 50 orang dalam sebuah populasi dan margin of eror yang ditetapkan adalah $5 \%$ atau 0,05 . Perhitungannya adalah sebagai berikut:

$$
n=\frac{50}{1+50\left(0,05^{2}\right)}=40
$$

\section{Konsep Pengukuran Variabel}

Adapun yang terjadi konsep pengukuran variabel dalam penelitian ini adalah sebagai berikut:

1. Karakteristik Responden
a. Nama
b. Umur (tahun)
c. Jenis Kelamin
d. Pekerjaan
e. Pendapatan per bulan

2. Mengukur tingkat kepuasan konsumen yang diberikan oleh pihak rumah makan, adapun variabel-variabel yang diukur sebagai berikut: a. Product (Produk), berkaitan dengan kualitas dan kuantitas produk yang ditawarkan produsen. Indikatorindikatornya sebagai berikut:

a) Kebersihan dalam penyajian.

b) Cita rasa produk.

c) Tampilan fisik produk.

b. Price (Harga), berkaitan dengan jumlah uang yang dikeluarkankonsumen untuk memperoleh suatu product. Indikatorindikatornya sebagai berikut:

a) Harga produk yang ditawarkan.

b) Kesesuaian harga dengan rasa produk yang disajikan.

c. Place (Tempat), berkaitan dengan fasilitas yang disediakan produsen. Indikatorindikatornya sebagai berikut:

a) Kemudahan tempat untuk dapat dijangkau oleh konsumen.

b) Tersedianya halaman parkir.

c) Kenyamanan yang ditawarkan oleh Lumbung Kawanua.

d) Kesan terhadap tampilan di Lumbung Kawanua.

e) Kebersihan ruangan.

f) Tersedianya fasilitas internet (wi-fi).

d. Promotion (Promosi), indikatorindikatornya sebagai berikut:

a) Pengiklanan yang dilakukan Restoran Lumbung Kawanua Manado.

b) Hubungan karyawan dan konsumen dalam mempromosikan produk.

e. Service (Pelayanan), berkaitan dengan pelayanan yang memuaskankepada konsumen. Indikator-indikatornya sebagai berikut:

a) Penampilan fisik (tangible) yaitu penampilan fisik dari karyawan.

b) Keandalan jasa pelayanan (reliability), yaitu kecepatan dalam menyanjikan product yang dipesan.

c) Daya tanggap yaitu kesigapan pihak restoran dalam menanggapi keluhan dari pelanggan (responsiveness). 
d) Keyakinan (assurance), yaitu pengetahuan karyawan terhadap product yang dijual.

e) Empati yaitu keramahan dan kesopanan karyawan dalam melayani konsumen (emphaty).

\section{Metode Analisis Data}

Analisis data yang digunakan merupakan analisis deskriptif yang dianalisis dengan menggunakan skala pengukuran sikap Likert Scale (Riduwan dalam Torey, 2016).

$$
\text { Tingkat kepuasan konsumen }=\frac{\text { Jumlah skor pengumpulan data }}{\text { Jumlah skor ideal }}=\times 100 \%
$$

Dengan indeks tingkat kepuasan yaitu:

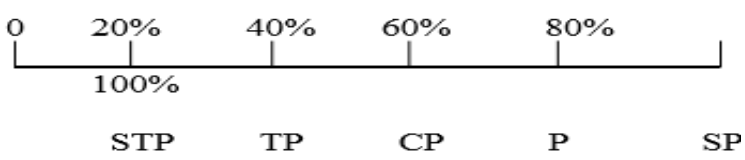

Gambar 1. Presentase tingkat kepuasan konsumen

Keterangan: Kriteria interpretasi skor

Angka 0\% - $20 \%=$ Sangat tidak puas

Angka 21\% - $40 \%=$ Tidak puas

Angka $41 \%-60 \%=$ Cukup puas

Angka $61 \%-80 \%=$ Puas

Angka 81\% - $100 \%=$ Sangat puas

\section{HASIL DAN PEMBAHASAN}

\section{Gambaran Umum Lokasi Penelitian}

Restoran Lumbung Kawanua Manado pertama kali di buka pada 16 Mei 2017, sehingga di bulan Mei 2020 Restoran Lumbung Kawanua Manado merayakan ulang tahun yang ketiga. Sebelum adanya Restoran Lumbung Kawanua Manado, Restoran yang sama telah lebih dulu ada di kota Balik Papan. Konsep yang di tawarkan dari restoran adalah menjajakan masakan dan makanan khas Manado. Pada area restoran dapat di temui beberapa jenis tanaman berupa tumbuhan bunga yang menambah suasana asri di seputaran restoran.

\section{Karakteristik Responden}

Jumlah responden yang diambil dalam penelitian ini berjumlah 40 responden diambil dari para konsumen restoran Lumbung Kawanua
Manado. Penyajian data mengenai identitas responden disini, yaitu untuk memberikan gambaran tentang keadaan diri pada responden. Adapun gambaran tentang responden yang telah menjadi sampel dalam penelitian ini di klarifikasikan berdasarkan umur, pendidikan terakhir, jenis kelamin, pekerjan utama dan pendapatan perbulan. Berikut ini akan dibahas mengenai kondisi dari masing - masing klasifikasi responden.

\section{Umur Responden}

Restoran Lumbung Kawanua merupakan salah satu restoran di Manado yang menyediakan berbagai macam hidangan menu. Dengan banyaknya pengunjung Restoran Lumbung Kawanua, maka konsumen yang ada didalamnya bervariasi berdasarkan umur. Umur seringkali menjadi penentu atas tindakan atau keputusan atau perilaku berkaitan dengan suatu produk. Tabulasi umur responden dapat dilihat sebagai berikut:

\begin{tabular}{lccc}
\multicolumn{2}{c}{ Tabel 1. Umur Responden } \\
\hline No. & Umur (tahun) & $\begin{array}{c}\text { Jumlah } \\
\text { Responden }\end{array}$ & $\begin{array}{c}\text { Persentase } \\
(\%)\end{array}$ \\
\hline 1. & $17-25$ & 9 & $22,5 \%$ \\
2. & $26-34$ & 19 & $47,5 \%$ \\
3. & $35-42$ & 11 & $27,5 \%$ \\
4. & $>43$ & 1 & $2,5 \%$ \\
\hline & Jumlah & $\mathbf{4 0}$ & $\mathbf{1 0 0 \%}$ \\
\hline
\end{tabular}

Sumber: diolah dari data primer.

Tabel 1 dapat di ketahui bahwa responden terbanyak adalah usia antara 26 34 tahun yaitu sebanyak 19 orang atau 47,5 $\%$, diikuti denganusia responden $35-42$ tahun sebanyak 11 orang atau $27,5 \%$. Usia responden 17 - 25 tahun sebanyak 9 orang atau $22,5 \%$, dan usia responden $>43$ tahun sebanyak 1 orang atau 2,5\%. Hal ini dikarenakan usia tersebut pada umumnya seseorang dalam usia produktif atau bekerja dan memiliki keinginan untuk menikmati kuliner sekelas restoran baik untuk kepuasan diri sendiri, rekreasi keluarga, atau untuk menjamu kerabat dan rekan kerja. Sedangkan untuk responden berusia $>43$ tahun yaitu hanya 1 orang atau 2,5\% dengan status karyawan. Rata-rata responden memiliki kepentingan rapat atau sekedar menikmati sajian makanan dan mengabadikan momen bersama teman-teman dan keluarga. 


\section{Jenis Kelamin Responden}

Jenis kelamin tentunya sangat mempengaruhi seseorang dalam memilih atau membeli suatu produk. Jumlah responden menurut jenis kelamin disajikan dalam tabel berikut ini.

\begin{tabular}{ccc} 
Tabel 2. Jenis Kelamin Responden & \\
\hline Jenis Kelamin & $\begin{array}{c}\text { Jumlah } \\
\text { Responden }\end{array}$ & Persentase \\
\hline Laki-laki & 23 & $57,5 \%$ \\
Perempuan & 17 & $42,5 \%$ \\
\hline Jumlah & $\mathbf{4 0}$ & $\mathbf{1 0 0 , 0 0}$ \\
\hline
\end{tabular}

Sumber: diolah dari data primer.

Tabel 2 dapat kita ketahui responden terbanyak adalah laki- laki sebanyak 23 orang dengan presentase $57,5 \%$, sedangkan responden perempuan adalah 17 orang dengan presentase $42,5 \%$. Hal ini sangat menunjukan bahwa lakilaki lebih konsumtif dan mudah tertarik untuk mencoba kuliner bahkan berekreasi mengajak keluarga daripada perempuan.

\section{Pekerjaan Responden}

Pekerjaan seringkali mempengaruhi perilaku seseorang dalam mengambil keputusan. Selain itu pekerjaan pada umumnya juga mencerminkan satu bentuk perilaku pembelian tertentu terhadap suatu produk. Tabulasi responden mengenai pekerjaan disajikan dalam tabel berikut ini:

Tabel 3. Pekerjaan Responden

\begin{tabular}{lcc}
\multicolumn{1}{c}{$\begin{array}{c}\text { Pekerjaan } \\
\text { Responden }\end{array}$} & $\begin{array}{c}\text { Jumlah } \\
\text { Responden }\end{array}$ & Persentase \\
\hline Pelajar/Mahasiswa & 3 & $7,5 \%$ \\
PNS & 11 & $27,5 \%$ \\
Swasta & 18 & $45 \%$ \\
Lainnya & 8 & $20 \%$ \\
\hline Jumlah & $\mathbf{4 0}$ & $\mathbf{1 0 0 \%}$ \\
\hline Sumber: diolah dari data primer. &
\end{tabular}

Tabel 3 menunjukkan bahwa pekerjaan sebagian besar responden adalah swasta yaitu sebanyak 18 orang atau $25 \%$, diikuti oleh responden yang bekerja sebagai PNS yaitu sebanyak 11 orang atau $27,5 \%$ kemudian lainnya sebanyak 8 orang atau $20 \%$, dan dengan status pelajar/mahasiswa sebanyak 3 orang atau $7,5 \%$. Hal ini menunjukan bahwa mayoritas pengunjung Lumbung Kawanua adalah swasta dan PNS. Dua golongan tersebut merupakan konsumen potensial pada jenis usaha kuliner.

\section{Pendapatan/Bulan Responden}

Tabel disajikan mengenai responden berdasarkan tingkat penghasilan. Tingkat penghasilan juga mencerminkan kemampuan seseorang dalam memilih produk dan jasa.

Tabel 4. Pendapatan/ Bulan Responden

\begin{tabular}{lcc}
\multicolumn{2}{c}{ Tabel 4. Pendapatan/ Bulan Responden } & \\
$\begin{array}{l}\text { Tingkat } \\
\text { Pendapatan (Rp) }\end{array}$ & Jumlah Responden & Persentase \\
\hline$<1.000 .000$ & 3 & $7,5 \%$ \\
$1.000 .000-2.000 .000$ & 2 & $5 \%$ \\
$3.000 .000-4.000 .000$ & 19 & $47,5 \%$ \\
$>4.000 .000$ & 16 & $40 \%$ \\
\hline Jumlah & $\mathbf{4 0}$ & $\mathbf{1 0 0 \%}$ \\
\hline Sumber: diolah dari data primer. &
\end{tabular}

Tabel 4 menunjukkan bahwa tingkat penghasilan terbanyak adalah 3.000.000 4.000.000 sebanyak 19 orang atau $47,5 \%$, diikuti tingkat penghasilan > 4.000.000 sebanyak 16 orang atau $40 \%$, kemudian tingkat penghasilan < 1.000.000 sebanyak 3 orang atau 7,5\%, dan tingkat penghasilan $1.000 .000-2.000 .000$ sebanyak 2 orang atau $5 \%$. Tingkat penghasilan responden sangat dipengaruhi oleh jenis pekerjaan responden.

\section{Mengukur Tingkat Kepuasan Konsumen \\ Restoran Lumbung Kawanua Manado}

Mengukur tingkat kepuasan konsumen sangat dibutuhkan oleh pihak yang terkait dalam hal ini Restoran Lumbung Kawanua Manado tujuannya agar dapat mengetahui kelebihan maupun kekurangan dari restoran tersebut agar restoran dapat maju dan mendapat keuntungan yang besar. Dalam hal ini tingkat kepuasan konsumen yang diukur adalah menggunakan 5 Aspek yakni: product, price, place, promotion dan Service. Pengukuran tingkat kepuasan konsumen restoran Lumbung Kawanua Manado yaitu sebanyak 40 responden terdiri dari 17 perempuan dan 23 laki-laki, yang rata-rata berusia antara 20-60 Tahun. Dengan tingkat pekerjaan pelajar/mahasiswa 3 orang, PNS 11 orang, swasta 18 orang, lainnya 8 orang.

\section{Produk (product)}

Produk meliputi apa saja yang ditawarkan di Restoran Lumbung Kawanua Manado. Pengkuran kepuasan konsumen dilihat dari kualitas produk adalah untuk jenis usaha yang dikelola Restoran Lumbung Kawanua Manado. 


\section{Rekapitulasi Kepuasan Konsumen Dari Segi Pernyataan Produk}

Pernyataan mengenai produk yang ditawarkan dilihat dari total skor, indeks kepuasan kosumen dan interpretasi

\begin{tabular}{|c|c|c|c|c|}
\hline No. & Pernyataan & $\begin{array}{l}\text { Total } \\
\text { Skor }\end{array}$ & $\begin{array}{c}\text { Indeks } \\
\text { Kepuasan } \\
\text { Konsumen }\end{array}$ & Interpretasi \\
\hline 1. & $\begin{array}{l}\text { Kebersihan } \\
\text { dalam } \\
\text { penyajian } \\
\text { produk }\end{array}$ & 182 & $91 \%$ & $\begin{array}{l}\text { sangat puas } \\
\text { (SP) }\end{array}$ \\
\hline 2. & $\begin{array}{l}\text { Cita rasa } \\
\text { produk }\end{array}$ & 163 & $81 \%$ & $\begin{array}{l}\text { sangat puas } \\
\text { (SP) }\end{array}$ \\
\hline 3. & $\begin{array}{l}\text { Tampilan fisik } \\
\text { produk }\end{array}$ & 161 & $81 \%$ & $\begin{array}{l}\text { sangat puas } \\
\text { (SP) }\end{array}$ \\
\hline & Jumlah & 506 & $84,3 \%$ & $\begin{array}{l}\text { sangat puas } \\
\text { (SP) }\end{array}$ \\
\hline
\end{tabular}

Tabel 5 dapat dilihat bahwa pernyataan tertinggi adalah kebersihan dalam penyajian produk dimana kebersihan dalam penyajian produk menyangkut kualitasnya, citra rasa produk baik, tampilan fisik produk dapat membuat konsumen Restoran Lumbung Kawanua Manado tertarik terhadap produk yang ditawarkan dan interpretasi 3 pernyataan produk tergolong Sangat Puas (SP).

\section{Harga (Price)}

Pengukuran kepuasan konsumen Harga yang ada di Restoran Lumbung Kawanua Manado dapat dilihat dari jenis usaha yang dikelolah oleh Restoran Lumbung Kawanua Manado.

\section{Rekapitulasi Total Skor Tingkat Kepuasan Konsumen Dari Segi Harga}

Pernyataan mengenai harga yang ditawarkan dilihat dari total skor, indeks kepuasan kosumen dan interpretasi.

Tabel 6. Rekapitulasi Total Skor Tingkat Kepuasan Konsumen Dari Segi Harga

\begin{tabular}{|c|c|c|c|c|}
\hline No. & Pernyataan & $\begin{array}{l}\text { Total } \\
\text { Skor }\end{array}$ & $\begin{array}{c}\text { Indeks } \\
\text { Kepuasan } \\
\text { Konsumen }\end{array}$ & Interpretasi \\
\hline 1. & $\begin{array}{l}\text { Harga produk } \\
\text { yang } \\
\text { ditawarkan }\end{array}$ & 153 & $76 \%$ & Puas (P) \\
\hline 2. & $\begin{array}{l}\text { Kesesuaian } \\
\text { harga dengan } \\
\text { rasa produk } \\
\text { yang } \\
\text { disajikan }\end{array}$ & 145 & $72 \%$ & Puas (P) \\
\hline & Jumlah & 298 & $74 \%$ & Puas (P) \\
\hline
\end{tabular}

Tabel 6 dapat dilihat bahwa pernyataan harga produk yang ditawarkan dan kesesuaian harga dengan rasa produk yng disajikan memiliki pernyataan yang sama dimana dapat membuat konsumen Restoran Lumbung Kawanua Manado masih tertarik terhadap harga yang ditawarkan dan interpretasi 2 pernyataan harga tergolong Puas (P).

\section{Tempat (Place)}

Tempat sangat mempengaruhi pemasaran suatu produk kaitannya disini adalah tempat Restoran Lumbung Kawanua Manado yang memasarkan produk mereka.

\section{Rekapitulasi kepuasan konsumen dari segi Pernyataan tempat (place)}

Pernyataan mengenai tempat yang ditawarkan dilihat dari total skor, indeks kepuasan kosumen dan interpretasi.

Tabel 7. Rekapitulasi Total Skor Tingkat Kepuasan Konsumen

\begin{tabular}{|c|c|c|c|c|}
\hline No. & Pernyataan & $\begin{array}{l}\text { Total } \\
\text { Skor }\end{array}$ & $\begin{array}{c}\text { Indeks } \\
\text { Kepuasan } \\
\text { Konsumen }\end{array}$ & Interpretasi \\
\hline 1. & $\begin{array}{l}\text { Kemudahan } \\
\text { tempat untuk } \\
\text { dapatdijangkau } \\
\text { konsumen }\end{array}$ & 176 & $87 \%$ & $\begin{array}{c}\text { Sangat Puas } \\
\text { (SP) }\end{array}$ \\
\hline 2. & $\begin{array}{l}\text { Tersedianya } \\
\text { halaman parkir }\end{array}$ & 140 & $70 \%$ & Puas (P) \\
\hline 3. & $\begin{array}{l}\text { Kenyamanan } \\
\text { yang } \\
\text { ditawarkan } \\
\text { oleh Lumbung } \\
\text { Kawanua }\end{array}$ & 194 & $97 \%$ & $\begin{array}{c}\text { Sangat Puas } \\
\text { (P) }\end{array}$ \\
\hline 4. & $\begin{array}{l}\text { Kesan } \\
\text { terhadap } \\
\text { tampilan di } \\
\text { Lumbung } \\
\text { Kawanua }\end{array}$ & 165 & $82 \%$ & $\begin{array}{c}\text { Sangat Puas } \\
\text { (P) }\end{array}$ \\
\hline 5. & $\begin{array}{l}\text { Kebersihan } \\
\text { ruangan }\end{array}$ & 180 & $90 \%$ & $\begin{array}{l}\text { Sangat Puas } \\
\text { (P) }\end{array}$ \\
\hline 6. & $\begin{array}{l}\text { Tersedianya } \\
\text { fasilitas } \\
\text { internet (wi-fi) }\end{array}$ & 186 & $93 \%$ & $\begin{array}{l}\text { Sangat Puas } \\
\text { (P) }\end{array}$ \\
\hline & Jumlah & 1041 & $86,5 \%$ & $\begin{array}{l}\text { SangatPuas } \\
\text { (SP) }\end{array}$ \\
\hline
\end{tabular}

Tabel 7 dapat dilihat bahwa pernyataan kenyaman yang ditawarkan oleh Restoran Lumbung Kawanua dan tersedianya fasilitas internet (wi-fi) memiliki pernyataan yang tinggi dimana dapat membuat konsumen Restoran Lumbung Kawanua Manado sangat tertarik terhadap tempat yang ditawarkan dan interpretasi 6 pernyataan harga tergolong Sangat Puas (SP). 


\section{Promosi (Promotion)}

Promosi terdiri dari 2 cara yang Restoran Lumbung Kawanua Manado terapkan yaitu promosi secara langsung (memberikan daftar menu makanan secara langsung kepada calon konsumen yang berkunjung disana dan menjelaskan menu-menu unggulan yang bersada disana) dan promosi secara tidak langsung (internet, media masa dan memasang spandukspanduk/banners dan bekerja sama dengan pihak-pihak yang lain).

\section{Rekapitulasi Kepuasan Konsumen Dari Segi Promosi}

Pernyataan mengenai promosi yang ditawarkan dilihat dari total skor, indeks kepuasan kosumen dan interpretasi.

Tabel 8. Rekapitulasi Total Skor Tingkat Kepuasan Konsumen Dari Segi Promosi

\begin{tabular}{|c|c|c|c|c|}
\hline No. & Pernyataan & $\begin{array}{l}\text { Total } \\
\text { Skor }\end{array}$ & $\begin{array}{c}\text { Indeks } \\
\text { Kepuasan } \\
\text { Konsumen }\end{array}$ & Interpretasi \\
\hline 1. & $\begin{array}{l}\text { Pengiklanan } \\
\text { yang dilakukan } \\
\text { Lumbung } \\
\text { Kawanua }\end{array}$ & 172 & $85 \%$ & $\begin{array}{l}\text { SangatPuas } \\
\text { (SP) }\end{array}$ \\
\hline 2. & $\begin{array}{l}\text { Hubungan } \\
\text { karyawan dan } \\
\text { konsumen } \\
\text { mempromosikan } \\
\text { produk }\end{array}$ & 174 & $86 \%$ & $\begin{array}{l}\text { Sangat Puas } \\
\text { (SP) }\end{array}$ \\
\hline & Jumlah & 346 & $85,5 \%$ & $\begin{array}{c}\text { Sangat Puas } \\
\text { (SP) }\end{array}$ \\
\hline
\end{tabular}

Tabel 8 dapat dilihat bahwa pernyataan pengiklanan yang dilakukan dan hubungan karyawan dengan konsumen memiliki pernyataan yang sama dimna dapat membuat konsumen Restoran Lumbung Kawanua Manado masih tertarik terhadap promosi yang dilakukan dan interpretasi 2 pernyataan promosi tergolong Sangat Puas (SP).

\section{Pelayanan (Servis)}

Pada kualitas pelayanan terdapat lima indicator pertanyaan mengenai kepuasan konsumen Restoran Lumbung Kawanua Manado, yaitu penampilan fisik, kendalan jasa pelayanan, daya tanggap, keyakinan, dan empati.

\section{Rekpitulasi Kepuasan Konsumen Dari Segi Pelayanan}

Pernyataan mengenai pelayanan yang ditawarkan dilihat dari total skor, indeks kepuasan kosumen dan interpretasi.
Tabel 9. Rekapitulasi Total Skor Tingkat Kepuasan Konsumen

\begin{tabular}{clccc}
\multicolumn{4}{c}{$\begin{array}{l}\text { Indeks } \\
\text { Dari Segi Pelayanan }\end{array}$} & Interpretasi \\
\hline No. & Pernyataan & $\begin{array}{c}\text { Total } \\
\text { Skor }\end{array}$ & $\begin{array}{c}\text { Kepuasan } \\
\text { Konsumen }\end{array}$ & \\
\hline 1. & $\begin{array}{l}\text { Penampilan } \\
\text { fisik }\end{array}$ & 159 & $79 \%$ & Puas (P) \\
2. & $\begin{array}{l}\text { Keadalan jasa } \\
\text { pelayanan }\end{array}$ & 167 & $83,5 \%$ & $\begin{array}{c}\text { Sangat Puas } \\
\text { (SP) } \\
\text { Daya tanggap }\end{array}$ \\
3. & 167 & $83 \%$ & $\begin{array}{c}\text { Sangat Puas } \\
\text { (P) } \\
\text { Sangat Puas } \\
\text { (P) }\end{array}$ \\
4. & $\quad$ Keyakinan & 166 & $83 \%$ & $\begin{array}{c}\text { Sangat Puas } \\
\text { (P) }\end{array}$ \\
5. & Empati & 168 & $84 \%$ & $\begin{array}{c}\text { SangatPuas } \\
\text { (SP) }\end{array}$ \\
\hline & Jumlah & $\mathbf{8 2 7}$ & $\mathbf{8 2 , 6 \%}$ &
\end{tabular}

Tabel 9 dapat dilihat bahwa pernyataan empati karyawan, daya tangap karyawan dan keyakinan karyawan yang ditawarkan oleh lumbung kawanua memiliki pernyataan yang tinggi dimana dapat membuat konsumen Restoran Lumbung Kawanua Manado merasa sangat tertarik terhadap pelayanan yang ditawarkan dan interpretasi 5 pernyataan harga tergolong Sangat Puas (SP).

\section{Rekapitulasi Tingkat Kepuasan Konsumen Restoran Lumbung Kawanua Kota Manado Dari Segi Produk, Harga, Tempat, Promosi Dan Pelayanan}

Tabel 10 menunjukkan rekapitulasi jumlah skor pengambilan data, dan interpretasi dari segi produk, harga, tempat, promosi dan pelayanan yang diberikan oleh Restoran Lumbung Kawanua Manado.

\begin{tabular}{|c|c|c|c|c|}
\hline & $\begin{array}{l}\text { Rekapitulasi } \\
\text { Kepuasan D } \\
\text { Lumbung Ka }\end{array}$ & $\begin{array}{l}\text { ah S } \\
\text { nterp } \\
\text { la Ma }\end{array}$ & ri 1 & $\begin{array}{l}\text { Data, Tingkat } \\
\text { umen Restoran }\end{array}$ \\
\hline No. & Pernyataan & $\begin{array}{l}\text { Total } \\
\text { Skor }\end{array}$ & $\begin{array}{c}\text { Indeks } \\
\text { Kepuasan } \\
\text { Konsumen }\end{array}$ & Interpretasi \\
\hline 1 & $\begin{array}{l}\text { Kebersihan Dalam } \\
\text { Penyajian Produk }\end{array}$ & 182 & $91 \%$ & $\begin{array}{l}\text { Sangat Puas } \\
\text { (SP) }\end{array}$ \\
\hline 2 & Cita Rasa Produk & 163 & $81 \%$ & $\begin{array}{l}\text { Sangat Puas } \\
\text { (SP) }\end{array}$ \\
\hline 3 & $\begin{array}{l}\text { Tampilan Fisik } \\
\text { Produk }\end{array}$ & 161 & $81 \%$ & $\begin{array}{l}\text { Sangat Puas } \\
\text { (SP) }\end{array}$ \\
\hline 4 & $\begin{array}{l}\text { Harga Produk } \\
\text { Yang Di } \\
\text { Tawarkan }\end{array}$ & 153 & $76 \%$ & Puas (P) \\
\hline 5 & $\begin{array}{l}\text { Kesesuaian Harga } \\
\text { Dengan Rasa } \\
\text { Produk Yang } \\
\text { Disajikan }\end{array}$ & 145 & $72 \%$ & Puas (P) \\
\hline 6 & $\begin{array}{l}\text { Kemudahan } \\
\text { Tempat Untuk } \\
\text { Dapat Dijangkau }\end{array}$ & 176 & $87 \%$ & $\begin{array}{l}\text { Sangat Puas } \\
\text { (SP) }\end{array}$ \\
\hline 7 & $\begin{array}{l}\text { Tersedianya } \\
\text { Halaman Parkir }\end{array}$ & 140 & $70 \%$ & Puas (P) \\
\hline 8 & $\begin{array}{l}\text { Kenyamanan } \\
\text { Yang Ditawarkan }\end{array}$ & 194 & $97 \%$ & $\begin{array}{l}\text { Sangat Puas } \\
\text { (SP) }\end{array}$ \\
\hline 9 & $\begin{array}{l}\text { Kesan Terhadap } \\
\text { Tampilan }\end{array}$ & 165 & $82 \%$ & $\begin{array}{l}\text { Sangat Puas } \\
\text { (SP) }\end{array}$ \\
\hline 10 & $\begin{array}{l}\text { Kebersihan } \\
\text { Ruangan }\end{array}$ & 180 & $90 \%$ & $\begin{array}{l}\text { Sangat Puas } \\
\text { (SP) }\end{array}$ \\
\hline
\end{tabular}




\begin{tabular}{|c|c|c|c|c|}
\hline 11 & $\begin{array}{l}\text { Tersedianya } \\
\text { Fasilitas Internet } \\
\text { (Wi-Fi) }\end{array}$ & 186 & $93 \%$ & $\begin{array}{l}\text { Sangat Puas } \\
\quad \text { (SP) }\end{array}$ \\
\hline 12 & $\begin{array}{l}\text { Pengiklanan Yang } \\
\text { Dilakukan }\end{array}$ & 172 & $86 \%$ & $\begin{array}{l}\text { Sangat Puas } \\
\text { (SP) }\end{array}$ \\
\hline 13 & $\begin{array}{l}\text { Hubungan } \\
\text { Karyawan Dan } \\
\text { Konsumen }\end{array}$ & 154 & $77 \%$ & Puas (P) \\
\hline 14 & Penampilan Fisik & 159 & $79 \%$ & Puas (P) \\
\hline 15 & $\begin{array}{l}\text { Keandalan Jasa } \\
\text { Pelayanan }\end{array}$ & 167 & $83,5 \%$ & $\begin{array}{l}\text { Sangat Puas } \\
\text { (SP) }\end{array}$ \\
\hline 16 & Daya Tanggap & 167 & $83,5 \%$ & $\begin{array}{l}\text { Sangat Puas } \\
\text { (SP) }\end{array}$ \\
\hline 17 & Keyakian & 166 & $83 \%$ & $\begin{array}{l}\text { Sangat Puas } \\
\text { (SP) }\end{array}$ \\
\hline 18 & Empati & 168 & $84 \%$ & $\begin{array}{l}\text { Sangat Puas } \\
\text { (SP) }\end{array}$ \\
\hline & Jumlah & 2.996 & $85,6 \%$ & $\begin{array}{c}\text { Sangat } \\
\text { Puas(SP) }\end{array}$ \\
\hline
\end{tabular}

Jumlah skor ideal untuk keseluruhan pertanyaan $=3.500$ (Sangat puas), jumlah skor terendah $=720$ (Sangat tidak puas). Berdasarkan data yang dihimpun dari 18 pertanyaan yang diajukan kepada 40 responden, maka diperoleh total skor adalah 2.996 dengan indeks tingkat kepuasan konsumen sebagai berikut sebagai berikut:

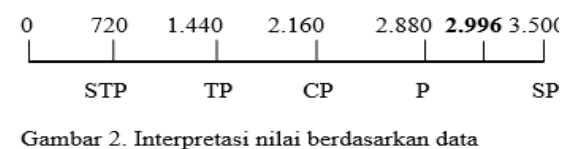

Secara persentase, angka indeks tingkat kepuasan konsumen terhadap Restoran Lumbung Kawanua Manado terletak pada:

Dengan indeks tingkat kepuasan yaitu:

$$
\begin{aligned}
& \text { Tingkat Kepuasan Konsumen }=\frac{2.996}{3.500} \times 100 \%=85,6 \% \\
& \quad \text { SP } \\
& \text { Gambar 3. Presentase tingkat kepuasan konsumen }
\end{aligned}
$$

Berdasarkan hasil analisis menggunakan skala likert, maka dapat diketahui bahwa angka indeks tingkat kepuasan konsumen Restoran Lumbung Kawanua Manado dari segi produk, harga, tempat, promosi dan kualitas pelayanan berada pada titik $85,6 \%$ tergolong sangat puas. Setiap konsumen yang datang ke Restoran Lumbung Kawanua Manado pasti memiliki kepentingan yang berbeda-beda. Sebanyak 18 indikator pertanyaan tentang kepuasan konsumen baik dari segi produk, harga, tempat promosi dan pelayanan karyawan. Dalam penelitian ini telah menunjukkan rata-rata kepuasan konsumen berada pada tingkat sangat puas. Hal ini menunjukkan bahwa secara keseluruhan pengelola Restoran Lumbung Kawanua Manado telah mencapai tingkat kepuasan konsumen meskipun masih ada beberapa indicator yang perlu diperhatikan. Masalah utama berada pada segi harga yang dimana konsumen merasa cukup puas dengan harga ditawarkan oleh Restoran Lumbung Kawanua Manado. Pada indikator harga pihak pengelola Restoran Lumbung Kawanua Manado harus lebih memperhatikan karena konsumen merasa harga yang terlalu mahal jika dibandingkan dengan restoran khas makanan Manado lainnya.

Indikator dari tampilan fisik dari karyawan diharapkan karyawan Restoran Lumbung Kawanua Manado dapat memberikan senyuman yang ramah kepada setiap konsumen. Berdasarkan hasil wawancara kepada konsumen, konsumen merasa karyawan Restoran Lumbung Kawanua Manado kurang memberi senyum yang ramah kepada setiap pelanggan. Sehingga hal ini dapat meningkatkan kepuasan konsumen terhadap pelayanan dari Restoran Lumbung Kawanua Manado.

Berdasarkan hasil pengambilan data keseluruhan terdapat 5 variabel yang dinilai oleh konsumen Restoran Lumbung Kawanua Manado yaitu dari segi produk, harga, tempat, promosidanpelayanan. Dari 5 variabeltersebut tempat yang memiliki tingkat kepuasan konsumen yang paling tinggi yaitu sebesar $86,5 \%$. Hal ini menunjukkan bahwa konsumen merasa sangat puas terhadap seluruh indikator tempat yang disajikan oleh pihak Restoran Lumbung Kawanua Manado.

\section{KESIMPULAN DAN SARAN}

\section{Kesimpulan}

Indeks kepuasan konsumen dilihat dari segi produk, harga, tempat, promosi dan pelayanan adalah sebesar $85,6 \%$. Hal ini menunjukkan bahwa konsumen sangat puas dengan produk, harga, tempat, promosi dan pelayanan yang ditawarkan oleh Restoran Lumbung Kawanua Manado. 


\section{Saran}

Kepada pihak manajemen Restoran Lumbung Kawanua Manado disarankan untuk mempertahankan kinerja yang selama ini membuat pelanggan merasa puas.

\section{DAFTAR PUSTAKA}

Dianto, I. W. 2013. Analisis Kepuasan Konsumen Waroeng Steak\&Shake JL. Cendrawasih NO.30 Yogyakarta. Fakultas Ekonomi universitas Negeri Yogyakarta.
Hardyasar, A. 2017. Tingkat Kepuasan Konsumen Restoran Pondok Hijau Kota Manado. Jurnal. Agri-SosioEkonomi. Unsrat Manado.

Novrianto, J. 2016. Analisis Kepuasan Pelanggan Pada Restoran Sop Tunjang Pertama (M1) Di Pekanbaru. Jurnal. Universitas Islam Riau.

Torey, J. 2016. Analisis Tingkat Kepuasan Konsumen terhadap produk dan pelayanan Di Rumah Kopi Billy di Cabang Megamas Manado. Jurnal. AgriSosiekonomi. Unsrat Manado. 